特 集 ニューメディア

\title{
2-6ニューメディアとホームエレクト ロニクスの進展
}

正会員 佐々木 正 $^{+}$

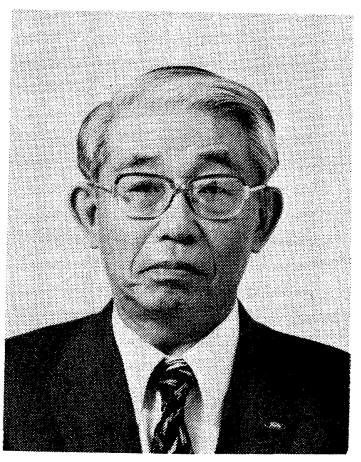

1. まえがき

近年, エレクトロニクスは, 半導体技術の急速な発 展により私達の生活の中にも深く係りをもつようにな つた。すなわち, 小型で高性能なコンピュー夕の出現 は家庭の電化機器や $\mathrm{AV}$ 機器の高機能化をもたらし, 私達の生活の心の満足度を満たしつつある。また,さ らに新しい通信技術を生み, 放送分野では今までのラ ジオやテレビ放送に加え, 文字多重放送, 衛星放送な ど新しい放送が開始された。

一方, 有線通信分野では高度情報通信システム, す なわち INSの実験が東京・三鷹地区で開始され，ま た，ビデオテックスサービスも昨年 11 月末にキャプ テンシステムとして東京や大阪地区で本サービスが開 始され, 新しい情報伝送（ニューメディア）が私達の 家庭にも入って来た。

このほかに, ニューメディアと呼ばれている新しい 情報媒体によるサービスは, 放送分野ではファクシミ リ放送, 放送衛星を用いる高品位テレビ放送, AM ステレオラジオ放送, PCM 放送, 静止画放送など盛 だくさんな放送が用意されている。有線通信分野では ホームファクシミリやテレビ電話, 画像応答システム (VRS), さらに, 地域社会と密着したケーブルテレ ビ (CATV) ネットワークによる各種サービスなどが 実験または小規模な実用試験に入っている.

また，ビデオディスクなどパッケージ系メディアの 開発も目ざましく, パーソナルコンピュータの普及に つれて, フロッピーディスクや電子スチルカメラのビ デオフロッピーディスク, さらに $8 \mathrm{mmVTR}$ の発売 など, 次々とニューメディアが家庭の情報機器の仲間 入りをして来ている.

さて, ここではコンピュータの出現により工業化社

$\dagger$ シャープ株式会社 副社長

"2-6 A Prospect of Home Electronics on New Media" by Tadashi Sasaki (Senior Executive Vise President, Sharpe Corporation, Nara)

特 集 $\square$ ニューメディア 2.1985 1995 年のニューメディア論
会から情報化社会へと移り替る社会的背景と，その影 響を受けて家電機器がどのように变わりつつあるか, また，どのような社会制度を見通す必要があるか，な ど不透明な今後 10 年の予測を述べ, 現在ホームエレ クトロニクス $(\mathrm{HE})$ の開発に関係している人達の参考 に少しでも役立てばと思う。

\section{2. 社会的 背景}

私達は過去, 物質に依存した農業化社会を経て, 物 質とエネルギーに依存した工業化社会の中で生活して 来た．そして今，情報を中心とした社会を迎えてい る.これらの過程は各方面で多くの人によって論じら れているので,ここでは省略し, さらに進んだ高度情 報化社会の中で, 私達の生活がどのように係り合いを もつのであろうか, 私見を述べてみよう.

半導体技術の発達は, 高性能な情報処理装置, 記憶 装置, とりわけ種々のコンピュータを生み, さらに高 度な通信技術の開発と相まって, あらゆる社会分野に 浸透しつつある。これらの情報化社会の構造を図 1 に 示している。すなわち, 我が国では国家レベルの情報

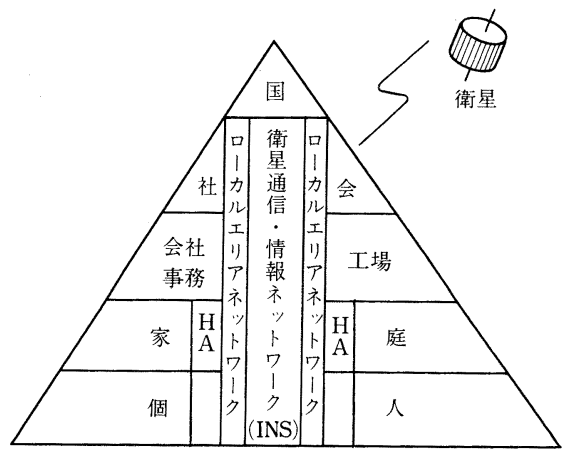

図 1 情報化社会の構造

* HE は Home Electronics の略で, Home Informatics や現在で はホームオートメーション (HA) などと呼ばれている.特に HA が定着しているようである. 
通信ネットワークとして各省庁, 電電公社, 国際電電 や電力会社などが独自にシステム構築をしている。な かでも電電公社の通信ネットワークは，あらゆる社会 階層に大きな影響をもっている。しかし，この形態は 電気通信法の改革により徐々に変わろうとしている. いずれにせよ，これは情報の国道ともいえる大切な部 分であり，特に我が国では情報品質と秘守の確保の面 から国のきびしい管理が必要と思われる. 次に地域社 会においては, 従来のテレビ共聴設備に端を発したケ ーブルテレビ (CATV) が一部の地域で運用され, ま た新しい計画も進行中である. 現在は双方向情報通信 ネットワークとしてオフィスや家庭を含む今後極めて 有用なポジションにある.

また，工場やオフィスでは，早くからコンピュータ を用いた独自の業務の合理化や自動化が進められて来 ている.特に,オフィスオートメーション (OA) やロ ボットなどの導入によるファクトリオートメーション （FA）などの名称で，すでに馴じみ深い分野である. なかでも $\mathrm{OA}$ はコンピュータ間通信やファクシミリ, テレテックス等で通信ネットワークとの係り合いが大 きい分野である。また，オフィス内や工場では数多い 端末を使用するため独自のネットワークを構築しはじ めている。これがローカルエリアネットワーク (LAN) と呼ばれているものである.

ここまでは電気通信ネットワークとして, すでに社 会がその恩恵を受けている．

では，家庭ではどうであろうか，現在は電話機を中 心とした双方向通信と, ビデオテックス端末機がテレ ビ受像機と有機的に結合し, 文字・図形情報のサービ スを受ける段階に来た。一方, 無線通信ではラジオ, テレビの放送サービスを個別に受けている，いわゆる スタンドアロン型の端末が多い。しかし, 徐々に家庭 内のシステム化の考えが芽ばえ, 郵政省や通商産業省 の関連で各企業が参画して研究会が活発に行われてい
る.

すなわち近い将来，ホームエレクトロニクスのシス テム化が実現し, 電気通信ネットワークと結合して, より良い生活が期待されている。すでにホームオート メーション（HA）と呼ばれ，OA，FAに並びその将 来が約束されている。しかし，多少前者と異なる点は 家庭に打ける合理化や自動化ではなく，より向上した 文化的で快適な生活を営むためのものでなければなら ないところである。

次に，個人レベルの情報化社会分野では“どこでも， 誰でも，いつでも情報が得られ，広答ができる”こと が必要である.今後はどのような形態で通信ネットワ ークと結合するのか明らかではないが, 自動車電話が 出現した以上は，これから少しずつ，その正体が見え てくるのかも知れない。いずれにせよ，無線通信シス テムが主流となることは間違いないだろう。この分野 は一部でパーソナルオートメーションと呼ばれてい る。

以上述べた各層の社会が有機的に結合してこそ高度 情報通信システムがその真価を発揮するのであって， そのときが高度情報化社会の全盛期であろう。これら のシステムは衛星を使って各国と結ばれ，地球レベル の社会が生まれよう. 今後 10 年以内に実現して欲し いものである。

\section{3. ホームエレクトロニクスの発展過程}

昭和 40 年前後, 電卓用の LSI から端を発し, マイ コンはあらゆる民生機器, とりわけ家電機器に使われ ている，省力化, 簡便性, 多機能化などその用途は多 岐にわたっているが, 家電機器はすべてではないが, 複合化, サブシステム化, トータルシステム化の方向 へと姿を変えようとしている。

図 2 は, その変化発展の過程を示したものである. まず，スタンドアロン型を第 1 期としよう. 空調, 調

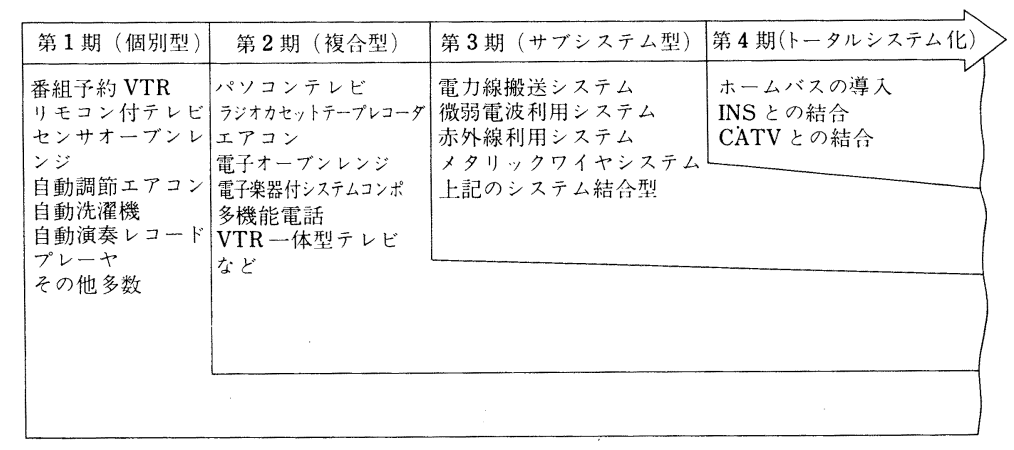

図 2 ホームエレクトロニクスの発展過程 


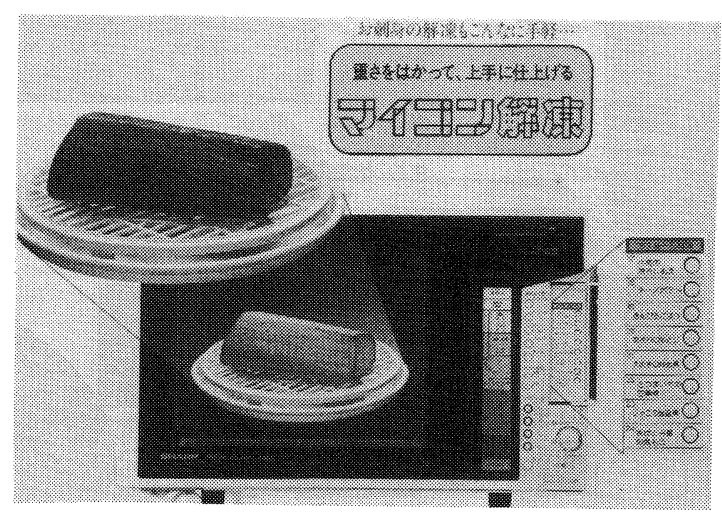

図 3 センサ電子レンジの一例

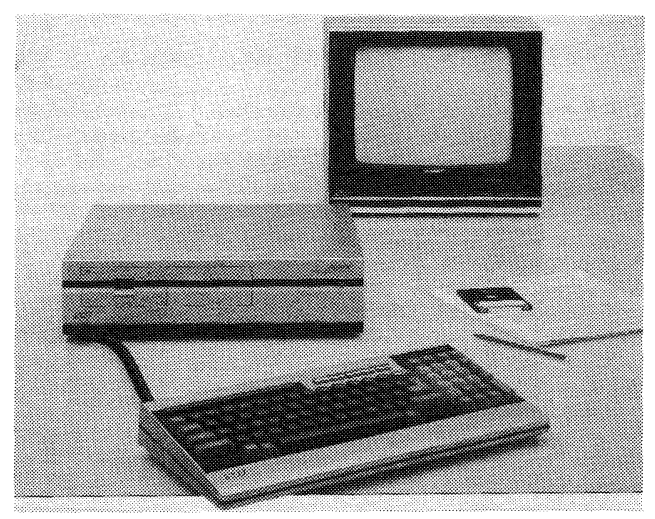

図 4 パソコンテレビの一例

理, ランドリー機器などでは省力化のためマイコンを 中心にセンサおよびアクチュエータとの組合せによ り，いつも快適な住空間を実現し，また，仕上りの良 い調理を実現したり，洗濯などにも工夫がこらしてあ る。

図 3 に,これらの代表例として電子レンジを挙げて みた. $\mathrm{AV}$ 機器でも自動演奏のレコードプレーヤ, 番 組予約やリモコンのできるVTR, テレビ受像機など もこの種の機器であり, さらに機能面の改良は加えら れるであろうが, スタンドアロン型の機器は今後も利 用されるであろう。

次は複合型機器の出現で, 第 2 期創出期と呼ぶこと にする。空調機器では冷暖房, 除湿, 空気清浄機能を 一体化した複合型エアコン, AV 機器では電子楽器付 きシステムコンポの複合型音響機器や, パソコンテレ ビが挙げられる. 図 4 は代表的な複合機能機器として パソコンテレビを示している.

最近になって, 家庭内のセキュリティシステムや電 灯のオン・オフ, インターホンや来客用テレビカメラ など，端末機器をコントロールする制御機をもった家

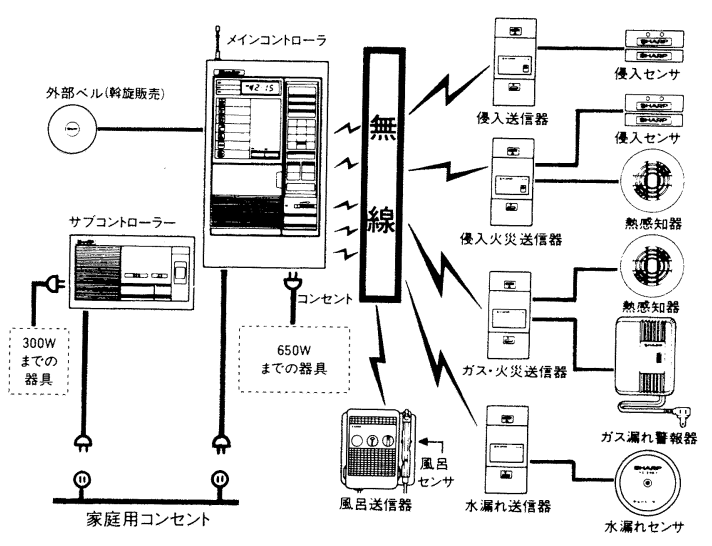

図 5 家庭情報システムの一例

庭情報システムや, 電話回線を使って家電機器をコン トロールするテレコントロールシステムなどが商品化 されはじめた。これらは情報の伝送手段として電力線 や電波, 光, メタルワイヤなどを個々に利用してい る.また $\mathrm{AV}$ 機器では 21 ピンコネクタの使用により 各機器の接続を可能にしている.

これらは本格的なシステムとは呼べないのでサブシ ステムと名付け, 第 3 期創出期としておこう。この種 のサブシステムは, サービス面から有用となれば, 種々のものが創出されるであろう。一例として, 家庭 情報システムを図 3 に示す.

ここまでが，現在すでに創出されている段階であ り, 次に述べるトータルシステムとして取扱う第 4 期 創出期のシステムとは, いま調查研究が始まったホー ムバスシステムを中心としたホームオートメーション （HA）であり, 前述の高度情報通信ネットワークと結 合するものと思われる。

\section{4. 今後のホームエレクトロニクスの姿}

郵政省の「家庭における情報化調査研究会」では, サ ービス面を中心に, マンマシンインタフェースやホー ムバスの技術的条件, 諸制度の見直しやアセスメント など幅広く調查し, 今後 10 年間のホームエレクトロ ニクスのあるべき姿を提言している.

これに対し，ホームバスシステムなど家庭の中に受 け入れられることはないだろうとの発言もよく聞く. しかし，いずれにせよ，私達の住居の形態は種々あ り，そこに住む人の考元も千差万別であることは確 かである、また，地域によりすべてのメディアが利用 できるとは限らない，だが仮定はあるものの，あるべ き姿を示し，技術開発，ニーズの発堀とサービスの方 策，ユーザ主体の利用機器の最低限の規格統一や諸制 


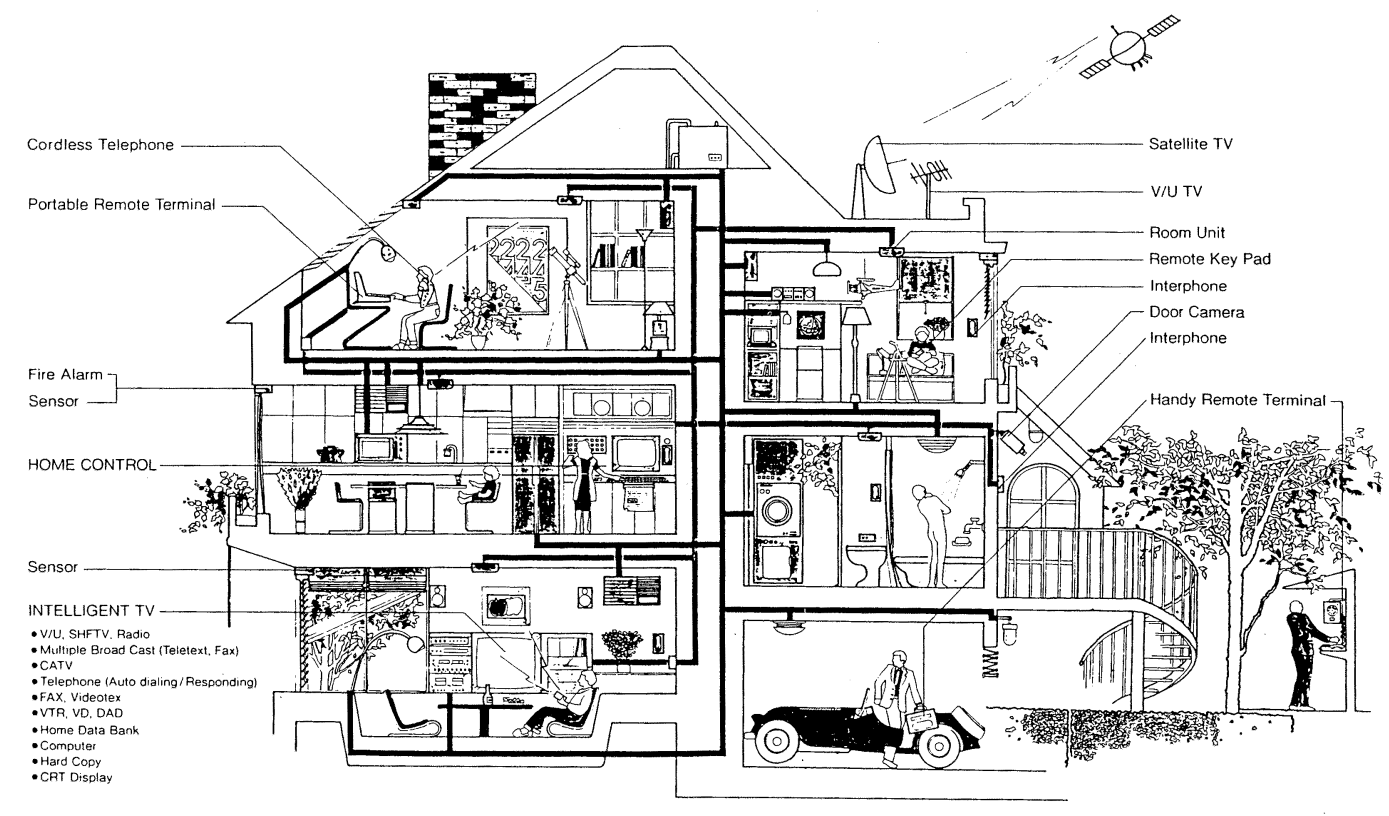

図 6 5 10 年後のホームエレクトロニクス概念図

度の確立を進める必要がある。

図 6 に 5 10 年後に実現するであろう HA の姿を 示した。外部情報としては放送メディアとしてラジ オ, テレビ ( $\mathrm{VHF}$ 抢よび $\mathrm{UHF})$, 衛星放送 (EHF) などがあり，1方向の同報通信である．特に衛星利用 の放送は, 我が国では全国同時同内容の情報サービス が可能で，今後極めて有用なメディアとなろう.

現在では, VHF および UHF はアンテナこそ異な るが, 1 本の同軸ケーブルで居間のテレビ受像機まで ブロードバンドのまま伝送されている，そして受像機 が複数台に増設されたときはケーブルが分岐され，ア ンテナは共用である。すなわち，一種のホームバスの 形態がとられている．今後は経済的な面からも衛星放 送の受信電波も同一ケーブルを利用する方向で技術開 発が進められよう。

有線系メディアに関しては現在, 電話機が接続され ている.今後はビデオテックス端末装置やホームファ クシミリ，パソコンなどが接続される予定で, 外部デ ータベースとのアクセスが可能となり, 唯一の双方向 通信が, 電話回線の延長としてホームバスを形成する であろう。

また，今後はハンディキャップを持った人や，高令 化社会の中で, ホームコントロールやホームセキュリ
ティシステムが不可欠となろう。これらは電話情報バ スや電力線搬送などを利用したサブバスを利用し，外 部端末へもアクセスできるシステムが実現しょう。ま た，個人としてはハンディターミナルやID, ICカー ドのホームベースへのアクセスも考えられる.

図 6 では具体的なホームバスの物理条件など示され ていないが, 各家庭に最も合致した形態が用いられ る. その時, ホームバスの形態は異なっても, 端末の 接続条件だけは共通のものに統一しておく必要があ る。

サービス内容は現時点で考えられるものが必ずしも 受け入れられるとは断言できないが, メディアがあれ ば，その利用方法は皆の力で新しいものが考えられる であろう。

この際, 特に考慮すべきことは, 安全対策やルール 化の早期検討と実現であろう. 国の指導により, 利用 者の知識を結集して, 10 年後のホームエレクトロニ クスを完成したいものである。これには経済性を考慮 した技術開発が何よりも決め手になろう。

テレビジョンなど新しい技術にたずさわる人達の責 任は重大であるが，必ず良いシステムが実現するもの と私は確信している.

(昭和 59 年 11 月 26 日受付) 